\title{
THE INFLUENCE OF THE POLICY OF THE RUSSIAN EMPIRE ON THE STATE OF MUSLIM CLERGY IN THE CENTRAL ASIAN STATES
}

\section{Nadira Makhkamova}

Doctor of Sciences, Professor, The Head of the Department "Humanity Sciences" of the Tashkent University of Information Technology named after Muhammad al Khwarizmi, Uzbekistan

\section{ABSTRACT}

This article highlights the changes that took place in the state of the Muslim clergy of the Central Asian region after its conquest by the Russian Empire, and also attempts to determine whether its influence on the local population remains as strong as in previous periods. The author of the article concludes that Islam in colonial Turkestan continued to remain an influential force in Muslim society, and the influence of the Muslim clergy was equally comprehensive, despite certain changes that took place in the system of Muslim education and legal proceedings.

KEYWORDS: - Conquest, influence, Muslim clergy, Islam, Sharia, Muslim education, spiritual and moral education, new-method schools, spiritual elite, legal proceedings, kaziyi, waqfs, missionary work.

\section{INTRODUCTION}

In the second half of the 19 th century as a result of the conquest of the Russian Empire, most of the region's territory was turned into its colony Turkestan, and a protectorate was established over the Bukhara Emirate and the Khiva Khanate. They retained their independence only formally. All political and administrative power in the Turkestan was concentrated in the hands of the colonial administration. However, the new government could not fail to take into account the status of the Muslim clergy in society and its influence on the local population, which constituted the overwhelming majority of the Turkestan. According to the census of the population of the Russian Empire in 1897, Muslims accounted for $96.41 \%$ in the Syrdarya region, $99.9 \%$ in Fergana, and $97.62 \%$ in Samarkand[1]. This article aims to reveal the changes that took place in the state of the Muslim clergy of the Central Asian region after its conquest by the Russian Empire and to determine whether its influence on the local population remained as comprehensive as in previous periods.

\section{Analysis of research and publications on the problem.}

When covering this issue, the greatest interest was aroused by the publications of the colonial period, since they were created by contemporaries and direct witnesses of the events that took place. In the process of implementing its policy in the region, the Russian administration should have taken into account the specifics of the lifestyle of the local population and, of course, its deep religiosity. Since the religion of Islam was a powerful and all-encompassing factor that determined all aspects of the life of the local population, it was first of all very important for all researchers studying Central Asia to have in Russian 
CURRENT RESEARCH JOURNAL OF HISTORY 2(8): 10-18, August 2021

DOI: https://doi.org/10.37547/history-crjh-02-08-03

ISSN 2767-472X

(C)2021 Master Journals

\section{Crossref do) 8 Google}

Accepted 15 th August, 2021 \& Published 20 th August, 2021

translation the main holy book of Muslims - the Koran, as well as Sharia law and various production regulations. and moral precepts that governed the inner life of Muslim society. A major event in Russian oriental studies was the publication of the Koran text in 1878 in Kazan, translated into Russian from the Arabic for the first time by the famous Kazan orientalist G.S. Sablukov. In 1894 and 1907 this edition was repeated, but along with the parallel Arabic text, in 1991 a reprint of the text of the Koran published in 1907 was published. In 1893 the Commentaries of Muslim Law "Hideya" translated from English under the editorship of the military governor of the Syrdarya region N.I. Grodekov[2]. In subsequent years, "Shariah articles on the legal relations of the Muslim population of the Turkestan region, extracted from the current Arabic exposition" on the issues of marriage, inheritance, donation,[3] Collection of Muslim decrees on the war with infidels[4], "Code of decency in the East" by Muhammad Sadyk Kashkari[5], Resolutions Muslim legislation on equity holders[6], Risolya (guild charters) of Sart artisans[7].

The great informational significance belonged to the articles, memoirs and other materials of educators, scientists, simply residents of Turkestan, published during this period, who spoke about their time, about the events they witnessed. For example, "The Kyrgyz story about the Russian conquests in the Turkestan", "A brief outline of the internal state of the Kokand Khanate before its conquest by the Russians" by Sattarkhan Abdulgaffarov, his essay "Muslim Ishans", etc. It should be noted that most of the colonial administration first of all selected for publication in Russian the testimonies of local authors who spoke laudatorily about the changes that had taken place in the region after the arrival of the Russians and thereby supported the colonialist policy of Russia. For example, the memoirs of Sattarkhan Abdulgaffarov, the impressions of the trip to Russia of the Samarkand merchant Mirza Bukharin Mirza Abdullin, the autobiography of the Kokand poet Zakirdzhan Furkat, cited by N.P. Ostroumov in the appendix to his work "Sarty. Ethnographic materials"[8].

No less valuable for researchers were the works of Central Asian authors published at that time in Russian about the earlier stages of the region's history: Notes of Mirza Shems Bukhari about some events in Bukhara, Kokand and Kashgar[9], Legend of Khoja-Akhrar[10], "History of Bukhara" by Muhammad Narshakhi[11], "Samaria" Abu Tahir Khoja[12], "Genealogical tree of the Turks" by Abu-Gazi-Bukhadurkhan[13], "Kandiya Malaya" by An-Nasafi alSamarkandi[14], etc. All these editions of local primary sources represent a very important section in historiography, they contributed great contribution to the development of oriental studies.

Among modern researchers of this problem, the publications of the researcher B. Babadjanov are of undoubted interest. His works touch upon such issues as the attitude of the Muslim clergy to the emerging, in connection with the annexation of the region to the Russian Empire, technical innovations, the split of the Muslim clergy in connection with the events taking place in the region, the Andijan uprising of 1898, its essence, goals and objectives, and also the personality of the leader of the uprising Dukchi Ishan, the degree of his influence on the local population, etc.[15]

\section{MaIn PART}

Under the influence of the changed political and economic situation - the inclusion of Turkestan in the orbit of the economic life of Russia, the active development of commodity-money relations, the intensive development of agriculture, the construction of railways and 
CURRENT RESEARCH JOURNAL OF HISTORY 2(8): 10-18, August 2021

DOI: https://doi.org/10.37547/history-crjh-02-08-03

ISSN 2767-472X

(C)2021 Master Journals

\section{Crossref do) 8 Google}

Accepted 15 th August, 2021 \& Published 20 th August, 2021

industrial enterprises for the processing of agricultural raw materials - a certain transformation of certain religious concepts and provisions took place. Nevertheless, the influence of Islam remained very strong in the province. The moral dignity of each individual, as before, was assessed in society by the degree of his obedience to the generally accepted Sharia law. A Muslim who does not completely and accurately perform the external rites of religion or who is engaged not only in prohibited, but even not approved by the Shariah actions (drunkenness, usury, slander, etc.), was considered an impious, unreliable person and was deprived of trust in his public environment. For example, he was not allowed to witness functions (and testimony in the East was a sign of high public trust) and guardianship, since these were godly deeds, and he violated divine commandments. Such perceptions are not quickly eradicated from public consciousness[16].

The entire system of Muslim education and spiritual and moral upbringing was the exclusive prerogative of the clergy, and Muslim jurisprudence was not just a science of law in the European sense, but was a religious law, therefore the ministers of mosques, teachers of schools and madrasas, Muslim lawyers were educated theologians, good scholars of the Koran, Sharia law and its interpretation. It determined the enormous influence and priority position in the society of the Muslim clergy. In the "Bukhara treatise on ranks and titles", written by a Bukhara scientist and statesman of the late XIX - early XX centuries. SharifjanMakhdum said that the first four posts established by "the sovereigns of Maverannahr in accordance with the brilliant Sharia" were posts that could only be held by clergy: judge Sheikhul-Islam; supreme judge kazi-kalyan; muhtasib (or rais) - overseeing the correctness of measures and weights, observing the established prices and fulfilling religious duties; mudarris - a teacher of a higher confessional school[17].

Under the tough political system of the Central Asian khanates, the clergy was in a special position and the sovereign emirs and khans were forced to reckon with them when making important decisions. This is clearly shown by the struggle for the opening of new-method schools in the Bukhara Emirate at the beginning of the 20th century. Their opening was facilitated by the support of the Bukharian kaziy Baddreddin, who, as S. Aini wrote, "being a person versed in the events taking place in the world, realizing the need, did not interfere with their discovery" [18] as well as the support of the famous Bukhara mufti Domullo Ikram[19]. The growing popularity of these schools alarmed the bulk of the conservative clergy, and they opposed the new schools. After the death of kaziy Badreddin in 1908, they obtained the emir's consent to close the new-method schools in September 1909. Moreover, schools were closed at the behest of another prominent clergyman of Bukhara - kazi-kalyan Burkhaniddin-sadr. He categorically refused the request of the Russian colonial administration addressed to the emir in September 1917 to restore these schools. The emir did not object to their discovery, but did not dare to do it without the consent of the KaziKalyan[20].

The transformation of Turkestan into a colony of the Russian Empire led to a direct clash of Muslim traditions, religious precepts and habitual foundations of life with completely new realities. Serious changes in the life of local society hit the Muslim clergy the hardest. First of all, it lost its political power, the traditional bureaucratic system was destroyed, the former khan's bureaucratic positions - kazi-kalyans, kushbegi, rais, previously held by clergy and giving them great power over the Muslim population - were abolished. In addition, a new religious stratum appeared in the region - the 
CURRENT RESEARCH JOURNAL OF HISTORY 2(8): 10-18, August 2021

DOI: https://doi.org/10.37547/history-crjh-02-08-03

ISSN 2767-472X

(C)2021 Master Journals

\section{Crossref do) 8 Google}

Accepted 15 th August, 2021 \& Published 20 th August, 2021

Christian clergy, which launched an active missionary activity, which had to be resisted in the struggle for spiritual leadership. The traditional social structure of society began to break down and social priorities began to change, new social strata appeared. A new social stratum of industrial entrepreneurs began to form from merchants, handicraftsmen and artisans, and a rural bourgeoisie - bayi appeared in the village. It changed their way of life and softened the indisputable significance of religion. New technical, construction, cultural and household innovations have appeared in the form of a telegraph, telephone, horse-drawn carriage, electricity, European urban architecture, furniture, household items, etc. Many Muslims began to build their houses in the Russian part of the cities and organize their life according to the European model. There was a blurring of sharp lines between people of different nationalities and different faiths, and, as the well-known ethnographer and Islamic scholar N.P. Ostroumov writes, "little by little the fear of the unknown passed, and religious intolerance weakened"[21].

All this factors made a split in the former monolithicity of the ranks of the Muslim spiritual elite, which faced the need to assess the new phenomena introduced by the Russians and to shape the attitude of the Muslim population towards them. The most fanatical and reactionary part of the clergy opposed everything new with hostility - both the Russian invasion of their lands and the changes brought about by the Russians. There was an explanation for this: all their life, studying their theological books based on the indisputable provisions of the Koran, Muslim theologians were deeply imbued with the spirit of their teaching and the impossibility of challenging it, so it was, of course, difficult for them to suddenly break seemingly indestructible commandments and go to understanding new phenomena. The Tashkent theologian Mirza Alim ibn Rahim Tashkandi, the Andijan Ishan Muhammad Ali (known as Dukchiishan) and many others were categorically opposed to the Russian colonialists. In the opinion of the researcher B. Babadjanov, they believed that one should not use objects produced by "other religions", or use them with extreme caution, in accordance with religious prescriptions. They ruled out any possibility of rapprochement with the Russians and called for all relationships with them to be reduced only to the inevitable minimum[22].

There was also another part of the Muslim spiritual elite, which, adhering to progressive views, recognized the possibility of close cooperation with the Russians, the need to acquire new knowledge, accept and apply technical innovations that came to the edge with them, since they are needed for the development of the regional people along the path of progress and civilization. Among them were the TuraKurgan kaziy Iskhak-khan of the tour ibn Dzhunaidallah Hajja (Ibrat); the outstanding educator, historian and poet Ahmad ibn Mir Nasir ibn Yusuf al-Hanafi al-Siddiqi al-Bukhari (Ahmad Danish), who served at the court of the Bukharian emir Nasrallah, and then as a kaziy in the provinces of Khuzar and Nahrapai; Tashkent Kaziy Mukhitdin-Khadja; Tashkent ishan Abdulkasim Khan, Bukhara educator and poet Abdurauf Fitrat. Iskhak Khan Tura believed that the clergy was obliged to call on believers to accept innovations and not to show their ignorance. In his work "Mizan-az-zaman" ("Scales of the era"), he wrote that the life of industry, crafts and science has come, to master which it is the duty of Muslims, and the ulama should call them to this, and those who reject new things, like machines or new types of clothing are showing their fanaticism[23].

Moreover, not only active enlighteners, like Fitrat or Ahmad Danish, who spoke to the younger generation wrote: "The ultimate goal of your 
CURRENT RESEARCH JOURNAL OF HISTORY 2(8): 10-18, August 2021

DOI: https://doi.org/10.37547/history-crjh-02-08-03

ISSN 2767-472X

(C)2021 Master Journals

\section{Crossref do) 8 Google}

Accepted 15 th August, 2021 \& Published 20 th August, 2021

inner aspirations and those promises that promise students of secular sciences is to encourage people to master knowledge so that these sciences develop forever on earth"[24]. But, what is especially important, theologians, whose main occupation was everyday communication with ordinary believers, also advocated the benefit of knowledge. For example, in the "Turkestan native newspaper" for 1885, the words of Ishan Abdulkasym-khan, very popular among the inhabitants of Tashkent, were quoted: the power of one's own knowledge"[25]. Kaziy of the Sibzar part of Tashkent Mukhitdin-Khoja, the son of the last Tashkent kazi-kalyan Khakim-Khoja, also spoke in favor of the benefits of knowledge. At the opening of the new Khoja-Akhrar mosque in Tashkent on July 29, 1888, he said: "Everywhere on the globe and at all times, educated people revered two subjects: one of them is religion, and the other is knowledge"[26].

At the same time, it should be noted that all progressive representatives of the Muslim clergy of Turkestan were characterized by the fact that, calling for the study of secular sciences and the use of new achievements of civilization, they did not seek and did not call for the betrayal of their religion, their religious beliefs. All of them were for the unwavering preservation of their faith. A. Fitrat in the essay "Rahbari-i Nazhot" ("The Way to Salvation") warns the reader that his calls for borrowing from Europeans and Russians, he does not call for the adoption of the faith of Christians and the issue of technical and scientific ties cannot and should not be put on the plane religious discussions[27]. Moreover, being deeply religious people, they urged fellow believers to acquire knowledge in order, in the words of Sattarkhan Abdulgaffarov, "to comprehend the works of their Creator and His perfect power as much as possible." "It is said in our theology," he wrote, "that God is wise and we believe this; but if we do not know anatomy, physics, chemistry, and other secular sciences, then we will not clearly understand what God's wisdom is. with the help of these secular sciences, we will be able to benefit ourselves and our neighbors more"[28]. In their works, they, using extensive theological knowledge, created them in a theological manner of presentation that was understandable to the people. Thus, Iskhak-khan of Tura, stylistically constructed his aforementioned work "Mizan-az-zaman" as a sermon with instructions and reminders in order to theologically justify and substantiate the possibility of using the technical innovations of a new civilization or household items. He writes: "New things appear every era and they should be weighed on the scales of the era". He considers them as existing in real life, not reflected in the Shariah, but also not contradicting it[29].

As mentioned above, the establishment of the colonial administration in the province had a number of negative consequences for the Muslim community. One of their manifestations was the deterioration in the quality of legal proceedings for the local population, carried out by the courts of the kazi. We have already noted that the qazis were not just lawyers, but educated theologians who knew the Koran perfectly well, many of its interpretations and interpretations of Sharia law. Before the conquest of the region by the Russian Empire, the kazis were appointed by the kazikalyan. Moreover, only from theologians who completed a full course of sciences in madrasa, where students had to show not only their abilities in knowledge, but also diligence and impeccable behavior in everyday life.

In accordance with the "Regulations on the management of the Turkestan region", for the indigenous population, people's courts were preserved - the courts of the kaziyev. But the position of the qazi-kalyan was abolished, and the qadis began to be elected by the society for 3 years. From the candidacy for the post of kaziy, no compulsory theological education was 
CURRENT RESEARCH JOURNAL OF HISTORY 2(8): 10-18, August 2021

DOI: https://doi.org/10.37547/history-crjh-02-08-03

ISSN 2767-472X

(C)2021 Master Journals

\section{Crossref do) 8 Google}

Accepted 15th August, 2021 \& Published 20th August, 2021

required, he simply had to be at least 25 years old, enjoy the respect and trust of the people, and not be tried and investigated. "He was, in the words of a major colonial official and ethnographer N. Lykoshin, the chosen one of the crowd, or rather of any particular group that won the elections"[30]. The absence of requirements for the educational level of future judges opened wide access to legal proceedings for illiterate and ignorant people, and this immediately affected its quality. An official of the colonial administration N. Mordvinov wrote to the Russkiy Vestnik in 1899: "Among modern Qazis there are many who do not know not only the Koran or Sharia, but are also almost illiterate. and the usual supervision over the knowledge of the Kazies and the moral side of their life in the previous court. The modern court of the Kazies has retained only the former form, and not the content, and the form is essentially spoiled"[31].

In addition, during the study period in the region, there was a general decrease in the level of knowledge among the Qazis with a higher Muslim education, that is, those who completed the full course of Turkestan madras. First of all, among them there was a deterioration in the knowledge of the Arabic language. And since all Muslim treatises on jurisprudence were written only in Arabic, this caused, first of all, the difficulty of reading them, and hence a detailed knowledge of Sharia law. Turkestan madrasa began to noticeably reduce the level of their education. Experts explained this by the fact that with the abolition of the position of the qazikalyan, supervision over the expenditure of income from the waqf property, on which the madrasa was kept, deteriorated. In addition, many significant waqfs were under the direct supervision of the Kokand khan and his prominent dignitaries, who considered the establishment of wealthy waqfs in favor of large madrasas the best way to glorify their name. Thus, objectively, they contributed to the development of Muslim education and theology. The removal of the state from the management of waqf property and the actual transfer of it to private individuals, who "no longer took the well-being of scientists and the prosperity of educational institutions to heart"[32], led to the fact that the incomes of the Turkestan madras began to fall, and with them the quality of teaching began to deteriorate them. And only in Bukhara, thanks to the presence of madras with very rich waqfs[33] and good supervision over them, according to the testimony of contemporaries, the study of Muslim jurisprudence continued to be maintained at the same high level and "well-trained scholars came out only from the madras of Bukhara"[34]. Therefore, the Governor-General of Turkestan constantly received requests for permission to travel to the Bukhara Emirate to receive theological education there[35].

And yet, despite all these negative moments, the Muslim population of the region accepted their courts of the Qazis as an inevitability given to them by the Sharia and did not even think about their possible replacement by a European court. Moreover, the officials of the colonial administration were surprised to note the fact that at the beginning of the 20th century. The Russian population began to make wide use of the "Regulations on the Administration of the Turkestan Territory" provided to them, the right to appeal to the people's courts - the courts of the kazievs - on claims against the local population. "It would seem", writes N.S. Lykoshin, "it is extremely absurd to prefer the decision of the case before the magistrate to the all referring to the legal subtleties of the Sharia courts. However, the Russian people in their affairs are increasingly turning to the people's court" [36]. It can be assumed that the Russians were attracted by the fact that the question was resolved quickly for the kaziy, while for the magistrate it could turn into a long trial. 
CURRENT RESEARCH JOURNAL OF HISTORY 2(8): 10-18, August 2021

DOI: https://doi.org/10.37547/history-crjh-02-08-03

ISSN 2767-472X

(C)2021 Master Journals

\section{Crossref do) 8 Google}

Accepted 15th August, 2021 \& Published 20th August, 2021

Conclusion. Facts show that at the beginning of the XX century. Islam still regulated the relationship of all strata of Muslim society, accompanied and directed the life and work of a farmer, artisan, and merchant. The new government, realistically assessing the internal situation in the region and realizing what a huge role the Muslim religion and its carriers, the Muslim clergy, play in the life of its population, left all spheres of their influence unchanged. Islam still remained the organizer of the legal, social, industrial, cultural, spiritual and moral spheres of life of all strata and strata of the Muslim population of the Turkestan Territory, which constituted its overwhelming majority. Those some transformations of the performance of religious rituals that occurred under the influence of the changed economic situation and some civilizational processes do not give grounds for asserting the existence of its crisis. Moreover, the Muslim clergy still owned the system of Muslim education and religious and moral education, people's legal proceedings, and regulated the everyday relations of Muslims. The strong positions of Islam in Turkestan had to be recognized by the colonial administration at the highest level. The Turkestan Governor-General S.M. Dukhovskoy in his all-subject report to Nicholas II "Islam in Turkestan", written in 1899 from the standpoint of the clear superiority of the Russian colonialist, stated that Islam in the region "still represents a solid force, with which we will inevitably have to reckon for a long time". And further he writes: "There is no need to speed up our missionary activity ... Islam in Turkestan is so strong that it would be in vain to count on a quick turnaround, especially in the generation that grew up under the charm of its current strength"[37]. Thus, Islam in colonial Turkestan continued to be an influential force in Muslim society.

\section{ReFERENCES}

1. The first general census of the population of the Russian Empire in 1897. Volume 86. Syrdarya region. - SPb., 1905. - S. XII; Volume 89. Fergana region - SPb., 1904. $\mathrm{S} . ! \mathrm{V}$; Volume 83. Samarkand region. - SPb., 1905. - S. V.

2. Hidoya. Commentaries of Islamic law. Per. from English, edited by N.I. Grodekov. Issue I-IV. - Tashkent, 1893. - Issue. I. - 513 p .; Issue II. - 462 p .; Issue III - 243 p.; Issue IV - 319 p.

3. Shariah articles with translation into Russian on the legal relations of the Muslim population of the Turkestan Territory, extracted from the indigenous current Arabic exposition, on the issues proposed by the senator Count K.K. Palen for discussion by the commission of natives scientists convened from three regions of the region in Tashkent. Tashkent, 1910 .-- 77 p.

4. Jihadali ghazavat (Translation of Muslim decrees on the war with the infidels). Per. Yarovoy-Ravsky. // Collection of materials on Islam. Volume 1. - Tashkent, 1899. pp.101-128.

5. Muhammad Sadik-i-Kashkari. Abd-ulsalihyn (Code of Decency in the East). Per. N. Lykoshina. // Collection of materials on Islam. Volume 2. - Tashkent, 1900 .-- Pp. 21-83.

6. Gramenitskiy S.M. Resolutions of Muslim legislation on equity holders. // Turkestan collection. Volume 459. - Tashkent, 1908. pp. 136-147.

7. Risola of Sart craftsmen. Collected and translated by M. Gavrilov. - Tashkent, 1912 
CURRENT RESEARCH JOURNAL OF HISTORY 2(8): 10-18, August 2021

DOI: https://doi.org/10.37547/history-crjh-02-08-03

ISSN 2767-472X

(C)2021 Master Journals

Crossref do: 81 Google

Accepted 15th August, 2021 \& Published 20th August, 2021

.- 59 p.

8. Ostroumov N.P. Sart. Ethnographic materials. Issue 1. Ed. 2nd supplemented. Tashkent, 1896 .-Pp. 190-215, 235-242, 243-263.

9. Some events in Bukhara, Kokan and Kashgar. Notes of Mirza Shems Bukhari. Per. V.V. Grigorieva. - Kazan, 1861.

10. Khoja-Akhrar-Vali. Legend. Per. from Persian by M. Aydarov with notes by P. A. Komarov. - Tashkent, 1896 .-- 90 p.

11. Muhammad Narshahi. Bukhara history. Translated from Farsi by N. Lykoshin under the editorship of V.V. Bartold. Tashkent, 1897 .-- 124 p. In 1904, Mulla Sultan published a lithographed edition of this work in New Bukhara.

12. Abu Tohir Khoja. Samaria (Description of antiquities and Muslim shrines of Samarkand). Per. V.L. Vyatkina. // Reference book of the Samarkand region. Issue VI. - Samarkand, 1899 .-- Pp. 153259.

13. Abu Ghazi Bahadur Khan. Family tree of the Turks. Per. and notes by G.S. Sablukov, afterword by N.F.Katanov. // News of the Society of Archeology, History and Ethnography at Kazan University. - Kazan, 1905. Volume XXI; 1906, Volume XXII.

14. An-Nasafi al-Samarkandi. Candia Small. Transl., Preface and notes by V.L. Vyatkin. // Reference book of the Samarkand region for 1906. VIII. - Samarkand, 1906 --Pp. 236-290.

15. Babadjanov B. Russian colonization of Central Asia: the view of local intellectuals // Islamic values and Central Asian realities. IFEAC Working Papers. Issue 7. (March 2004). - Tashkent, 2004. - S. 16 .; He's the same. Andijan Uprising of 1898:
"Dervish Gazavat" or Anti-Colonial Action? // Social sciences in Uzbekistan. - 2001. No. 2. - S. 25-30; No. 4 - S. 61-67; He's the same. The Andijan Uprising of 1898 and the "Muslim Question" in Turkestan (Views of the "Colonizers" and "Colonized") // https://crss.uz/2009/05/17/andizhansko e-vosstanie-1898-goda-i-musulmanskijvopros-v-turkestane-vzglyadykolonizatorov-lonizirovannyx. 2020 г.

16. Tornau. Features of Islamic law. - SPb., 1892 .-- Pp. 13-14.

17. Sharifjan-Makhdum. Bukhara treatise on ranks and titles (and on the duties of their bearers in medieval Bukhara). Translation and comments by A.A. Semenov. // Soviet Oriental Studies. Volume V. - M., - L., 1948 .- Pp. 139-140.

18. Aini S. History of the Mangyt emirs. Sobr. op. Volume 6. - M., 1975 .-- Pp. 306-307.

19. Umnyakov I.I. On the history of the new method school in Bukhara. // Bulletin of SAGU. - No. 16. - P. 90.

20. Khamraev A. Some features of the feudal mode of production in Bukhara in the XIX century. // From the history of Uzbekistan in the XIX - XX centuries. Collection of scientific works of the Tashkent State Pedagogical Institute.-Tashkent, 1975. - P. 10.

21. Ostroumov N.P. Sart. Ethnographic materials. Ed. 2. - Tashkent, 1896 .-- P. 101.

22. Babadjanov B. Russian colonization of Central Asia: the view of local intellectuals // Islamic values and Central Asian realities. IFEAC Working Papers. Issue 7. (March 2004). - Tashkent, 2004. - S. 16 .; He's the same. Andijan Uprising of 1898: "Dervish Gazavat" or Anti-Colonial Action? // Social sciences in Uzbekistan. - 2001. No. 2. - S. 25-30; No. 4 - S. 61-67. 
CURRENT RESEARCH JOURNAL OF HISTORY 2(8): 10-18, August 2021

DOI: https://doi.org/10.37547/history-crjh-02-08-03

ISSN 2767-472X

(C)2021 Master Journals

\section{Crossref do) 8 Google}

Accepted 15 th August, 2021 \& Published 20 th August, 2021

23. Ishaq Khan Tura ibn Junaydallah Hajj (Ibrat). Mizan-az-zaman. Preparation for publication, preface, text revision by prof. Hisao Komattsu, Bakhtiyar Babadjanov. Tashkent - Tokyo, 2001. - Preface. C-8, text l. 14 a-c, 24 c-25 c.

24. Ahmad Danish. For the edification of children about the benefits of crafts and occupations.// Travel from Bukhara to St. Petersburg. Favorites. - Dushanbe, 1960 .-P. 235.

25. Turkestan regional newspaper. - 1885. - № 22.

26. In the same place. - 1888. - No. 30.

27. Babadjanov B. Decree op. - S. 15.

28. Turkestan regional newspaper. - 1885. - № 13.

29. Iskhak Khan Tura (Ibrat). Decree op. Foreword. - p. 6.

30. Lykoshin N.S. Half life in Turkestan. Essays on the life of the indigenous population. Petrograd, 1916 .-- P. 56.

31. Mordvinov N.L. On the issue of the position of sedentary foreigners in Turkestan. // Turkestan collection. Volume. 454 .-Tashkent, 1908. p. 801.

32. Lykoshin N.S. Half life in Turkestan. - S. 68.

33. At the beginning of the $\mathrm{XX}$ century. in Bukhara, there were 172 madras, whose waqf property amounted to 3 million 700 thousand tangas, of which 33 madras were of the highest type: their income was 2 million 815 thousand tangas. - (Osroumov N.P. Introduction to the course of Islamic studies. - Tashkent, 1914. - P. 167).

34. Ostroumov N.P. Introduction to the course of Islamic studies. - S. 167.
36. Lykoshin N.S. Half life in Turkestan. - S. 107.

37. NA Uz, f. I-1, op. 11, d. 1832-a, ll. 2 vol., 6 vol.

38. Махкамова, Н. Р. (2009). Социальная структура общества на территории Узбекистана: традиции и трансформации (конец XIX в.-30-е годы XX в.). Ташкент: Aloqachi, 323.

39. Махкамова, Н. Р. (2009). Средние собственники Узбекистана-основа благополучия государства (история и современность).

40. Makhkamova, N., \& Tashkenbayeva, D. (2018). THE ROLE OF ISLAM IN REGULATING OF THE PRODUCTION SPHERE OF THE TURKESTAN SOCIETY. Theoretical \& Applied Science, (4), 67-71.

41. Makhkamova, N., \& Tashkenbayeva, D. (2019). Traditionalism, as a factor in the development of central asian society (XIXearly XX centuries.). International Journal of Innovative Technology and Exploring Engineering, 8(9), 933-938.

42. Shirinova F., N. Makhkamova., D. Tashkenbayeva., Z. Kasimova (2021). The Middle Owners of Uzbekistan - The Basis of Well-being of the State (Analysis of History and Modernity). Turkish Online Journal of Qualitative Inquiry (TOJQI). Pp. 2625-2637

35. See: NA Uz, f.I-1, op. 20, d. 46. 